\title{
The impact of human factor on labor productivity at the mining enterprises
}

\author{
Galina Pinigina ${ }^{1 *}$, Irina Kondrina ${ }^{1}$, Svetlana Smagina $^{2}$, Viktor Tatsienko ${ }^{3}$, and Anatoliy \\ Meshkov ${ }^{4}$ \\ ${ }^{1}$ T.F. Gorbachev Kuzbass State Technical University, Department of History, Philosophy and Social \\ Sciences, 650000 Kemerovo, 28 Vesennya st., Russian Federation \\ ${ }^{2}$ Kemerovo State University, Department of Psychology of Education, 650000 Kemerovo, 6 Krasnaya \\ st., Russian Federation \\ ${ }^{3}$ T.F. Gorbachev Kuzbass State Technical University, Institute of Industrial and Ecological Security, \\ 650000 Kemerovo, 28 Vesennya st., Russian Federation \\ ${ }^{4}$ JSC SUEK-Kuzbass, 652507 Leninsk-Kuznezkii, 1 Vasilieva st., Russian Federation
}

\begin{abstract}
The article describes the term "human factor" which implies a person involved in the organizational process in the diversity of his natural and socio-psychological characteristics. The necessity to identify the impact of human factor on labour productivity at the mining enterprises is proved. It is assumed that considering human factor can be one of the ways to increase labour productivity. A research technique of the complex mechanized team in order to identify the impact of human factor on its productivity is described. Definite research results and analysis which strongly support the assumption are given. The stages at which the human factor should be considered are analyzed. Based on the fact that person's mood determines all his vital functions, the following interpretation of the human factor was propose: to consider the human factor means to take into account everything that might spoil the mood of a person starting from his coming to the place of work till the work is finished. If it is necessary to provide high productivity, take care of the human mind. This thesis does not require proof and justification, it is obvious.
\end{abstract}

\section{Introduction}

In the world psychological and management literature the term "human factor" had been described long ago and come along with such conceptual partners as "human relations", "management style" and "psychological climate". Like any other term it is necessary to describe the term "human factor". What is the context of its use? The answer is simple: in this case it is a person involved in the organizational process in the diversity of his natural and socio-psychological characteristics [1-6].

\footnotetext{
* Corresponding author: ikondrina@mail.ru
} 


\section{Materials and Method}

It is difficult to overestimate the role of human factor in all spheres of activity. Even in 1936, the famous American expert in Management Dale Carnegie noted that even in such technical areas as engineering about $15 \%$ of financial success achieved by a specialist is due to purely technical knowledge and about $85 \%$ due to his art of human engineering, the personal characteristics of his character [7]. Western management theorists confirm that taking into account the human factor increases productivity [8-12]. It obtains a special importance at present post-industrial stage of technological development of the economy [13-15].

Unfortunately, we have been taking in stride the foreign experience in management issues, especially its social and psychological aspects. In recent years interesting papers on psychological management problems [16-18] have been published. As a result, a favorable situation for determining the influence of human factor on labour productivity at the mining enterprises [19-24] was created.

The survey covered 64 respondents - employees of the complex-mechanized mining team. Any professional activity to be implemented successfully requires certain personal qualities; we call them professionally-important (PIQ).

The work at the enterprises of coal-mining industry refers to the dangerous occupations that require human social-and-psychological readiness to work in extreme conditions, namely, the high level of such personal characteristics as responsibility, self-control, resoluteness and being a team player. The description of these professionally-important qualities is given below:

- Responsibility (people with the high level of this quality have a sense of duty, they are precise and accurate in affairs, like order in everything, conscious, conscientious and highly moral);

- Self-control (people with the high level of self-control are organized, able to control their emotions and behavior, to overcome the obstacles, bring to the end everything they start, aware of social demands and try to fulfill them);

- Resoluteness (people with the high level of resoluteness are brave, resolute, risktaking, able to withstand heavy loads; do not get lost confronting with unexpected circumstances);

- Being a team player (people with the high level of this quality keep good relations in the team, they are people friendly, unenvious, compliant, careful to some extent).

To the list of professionally-important qualities we added two qualities which, in our opinion, could influence the result of work in conditions of risk for life. These are selfconfidence and restraint:

- Self-confidence (people with the high level of self-confidence have adequate selfesteem, confident in their abilities, actively respond to all the events);

- Restraint (people with the high level of this quality control their emotions well; do not take hasty decisions; reasonable in assessing the events; balanced in dealing with people).

To measure these qualities in our respondents, we chose one of the most reliable and valid questionnaire in the world made by R.B. Cattell. Multivariate personality Cattell questionnaire is widely used in psycho-diagnostic practice. This test is reliable, versatile, practical, and provides comprehensive information about the individual. Questions reflect ordinary life situations.

In addition, this field of activity presupposes flexible nervous system of a person, allowing orient fast and right in extreme situations and mobilize for problems solution.

These features include the type of temperament and characteristics of human behavior. To identify the temperament of the respondents we chose the methodology of $\mathrm{H}$. J. Eysenck. 
The selection of this technique was due to the direct interconnection between conditions of dangerous profession and the dynamics of nervous processes in the human body. The more dangerous the work is the stronger the type of nervous system must be.

In modern society there is a task to improve the humanistic content of labor, i.e. to achieve maximum performance with optimum preservation of health and sufficient emotional and spiritual satisfaction. One of the factors that ensure the maximum performance of the employee is the psychological climate in the team, namely, satisfaction from working conditions and relationships, both between team members and between managers and subordinates. Accordingly, the respondents were offered a few questions, the answers to which allowed to analyze the psychological climate in the team.

The team consisted of six sections. Based on our research goals we ranked the sections by the results of output for 10 months in 2016. Then, to determine the impact of human factor on productivity, we ranked sections by the level of professionally-important qualities and qualities which could affect labour productivity of the respondents.

\section{Results and discussion}

Analysis of the results allowed stating the obvious influence of human factor on productivity of people working at the mining enterprises. Members of the section, which took the first place by the results of work for 10 months, have all professionally-important qualities and qualities which could affect the results of work and they were highly formed. Only the level of "being a team player" quality was not at the top, but it can be explained. All members of the section, including the section leader, were choleric, i.e. leaders. However, the psychological climate in the section was good: $63 \%$ of staff was satisfied with job and did not intend to change it; $68 \%$ were satisfied with relationships within the team and relationships with section leader.

Members of the section taken the second place by the results of work for 10 months had lower level of professionally-important qualities. However, the human factor was evident in the face of the section leader, whose professionally-important qualities were formed at a good level, and the analysis of the replies of section members to the questionnaire showed a great impact made by the section leader on the psychological climate: $100 \%$ of respondents were satisfied with job; $78 \%$ did not intend to change it; $89 \%$ were satisfied with relationships within the section and $100 \%$ were satisfied with the relationships with the section leader. Favorable psychological climate in the team and skillful leadership shown by the section leader made it possible to achieve good production results.

Three sections were practically at the same level by the working results. They were insignificantly different in professionally-important qualities. The level of professionallyimportant qualities of both members and section leaders were high enough.

The section taken the last place by the results of labor showed a disturbing pattern. All its members had low level of professionally-important qualities. The psychological climate in the section couldn't be called good: $35 \%$ were not happy with the relationships with the section leader, while $83 \%$ were satisfied with relationships with the section members; $58 \%$ of respondents said that they did not like the job and $75 \%$ would like to change it. With such atmosphere in the team there is a need in a strong section leader, but it cannot be said about the present one: his responsibility was not formed at the proper level; he had low selfcontrol; and was not a good team player. The impact of human factor on the results of work in the section was obvious.

The analysis of study results confirmed the hypothesis: considering the human factor can be one of the ways to increase the labour productivity at the mining enterprises.

Two factors deserve attention. The first, all respondents were people with a strong type of nervous system. This supports that people with a weak nervous system do not choose the 
job connected with the risk for life. The second factor concerns the high level of selfcontrol and resoluteness which had absolutely all respondents. This shows the influence of the job itself on the formation of personal qualities.

What stages should the human factor be considered on? First of all, at the recruitment stage. Every company should have job description for all positions which contains the description of the content and conditions of work and, more importantly, psychological requirements, that is, the list of professionally-important personal qualities. The psychologist determines the level of these qualities, and considers the possibility of taking the person to the workplace. It is interesting to work only when there is a maximum matching of professional skills to the professional requirements. If this condition is fulfilled the person will have pleasure from the labor process itself.

The next stage of considering the human factor is the formation of the team (group of workers, section, and so on.); appointment of the division head. The results of our study clearly confirmed this.

\section{Conclusion}

In conclusion we would like to underline the thesis: to consider the human factor means to take into account everything that might spoil the mood of a person starting from his coming to the place of work till the work is finished. Why is it mood? It is because the mood determines all human activity.

This thesis does not require proof and justification, it is obvious. Do you want a person to work hard, creative? Take care of his mood. Mood creates a desire to work. Convince the person in belonging to everything going on at the enterprise. It will be another drop in the formation of desire to do everything that depends on him personally in order to achieve overall success.

Is it necessary to convince that considering the human factor has a positive effect on the mood of all team? The quality of work and productivity always accompany a good sociopsychological climate in the team. Hence there should be an obvious psychological readiness of managers at mining enterprises.

\section{References}

1. H. Tichy, M. Devaney, Leaders of reorganization (Economics, 1990)

2. J. Sullivan, C. Snodgrass, Asia Pacific journal of management 8 (1991)

3. W.F. Ouchi, Theory Z: How American Business Land Meet the Japanese Challenge (1981)

4. M.R. Sethi, Q.B. Baloch, How to develop self Confidence and influence people by public speaking, published by pocket books (Simon and Shuster, 1956)

5. R.J. Deluga «Can work groups be made more effective?» Yes! (Academy of Management executive, August, 1994)

6. B.M. Bass, Handbook of leadership. Theory, research and management applications (New-York: The press division of Macmillan, 1990)

7. D. Carnegie, How to win friends and influence people (1998)

8. H. Cornelius, Sh. Faire, Everyone can win (Simon \& Shuster Australia, 1989)

9. H. MacKay, Swim with Sharks without being eaten: outself, outmanage, outmotivate and outnegotiate your competition (2005) 
10. K. Muangmukrafan, Factors in job satisfaction contributing to retention of employees in organization, (Thammasat University, Language Institute, 2006)

11. P. E. Hart, "Theories of firms" growth and generations of jobs (Review of Industrial Organization, 2000)

12. D. Leonard, W.C. Swap, Deep Smarts: how to cultivate and transfer enduring business wisdom (Boston, Harvard Business School, Press, 2005)

13. S. Zhironkin, E. Gasanov, O. Zhironkina, E. Taran, SHS Web of Conferences, 28, 01145 (2016)

14. A. Zhavoronok, M. Gasanov, S. Zhironkin, SHS Web of Conferences, 28, 01144 (2016)

15. S.A. Zhironkin, A.A. Khoreshok, M.A. Tyulenev, G.A. Barysheva, M. C. Hellmer, IOP Conf. Ser.: Mater. Sci. Eng., 142, 012127 (2016)

16. Sh. Akhmetova, A. Sakhanova, Ahmet Yesevi University, 31 (2004)

17. F. Fallahi, S. Soujudi, Human Resources management journal, 3 (2012)

18. M. Alwany, P. Ahmadi, Modarres, 5 (2002)

19. M. Tyulenev, E. Garina, A. Khoreshok, O. Litvin, Y. Litvin, E. Maliukhina, IOP Conf. Ser.: Earth Environ. Sci., 50, 012035 (2017)

20. M.Y. Blaschuk, A.A. Dronov, S.S. Ganovichev, IOP Conf. Ser. Mater. Sci. Eng., 142, 012128 (2016)

21. A.V. Koperchuk, A.V. Murin, V.V. Filonov, IOP Conf. Ser. Mater. Sci. Eng., 127, 012040 (2016)

22. M.Y. Blashchuk, A.A. Kazantsev, R.V. Chernukhin, App. Mech. Mat, 682, 418 (2014)

23. A.B. Efremenkov, A.A. Khoreshok, S.A. Zhironkin, A.V. Myaskov, IOP Conf. Ser.: Earth Environ. Sci. 50, 012009 (2017)

24. V.M. Zolotukhin, V.A. Gogolin, M.Yu. Yazevich, M.I. Baumgarten, A.V. Dyagileva, IOP Conf. Ser.: Earth and Envir. Sci., 50, 012027 (2017) 